\title{
Spontaneus subscapular abscess. A clinical case
}

\section{Absceso subescapular espontáneo. Caso clínico}

https://doi.org/10.23938/ASSN.0857

\author{
M. Fernández Pérez, I. Orradre Burusco, J. Mondragón Rubio, \\ L. Azcona Martínez de Baroja, I. Romero Redondo, D. Cornejo Jiménez
}

\begin{abstract}
Infections of the subscapular space are very infrequent entities, which is why their diagnosis (for which it is crucial to carry out magnetic resonance imaging or, failing that, computerized tomography) can prove complicated. This difficulty in making the diagnosis conditions the speed of treatment (surgical draining that can be accompanied by antibiotherapy), which is crucial for the medium and long-term prognosis.

We present the case of a patient who developed a spontaneous subscapular abscess that was drained using a delto-pectoral approach, with the subscapular space accessed via a medial route to the coracoids. The relevance of this case lies in its singular character and in the description of an approach that has only been used in two prior cases in the literature.
\end{abstract}

Keywords. Subscapular abscess. Spontaneous. Deltopectoral approach. Septic arthritis. Infection.

\section{RESUMEN}

Las infecciones del espacio subescapular son entidades muy poco frecuentes y, por ello, su diagnóstico (para el que resulta clave la realización de una resonancia magnética o, en su defecto, una tomografía computarizada) puede resultar complicado. Esta dificultad en el diagnóstico condiciona la rapidez en el tratamiento (drenaje quirúrgico acompañado o no de antibioterapia), que resulta clave para el pronóstico a medio y largo plazo.

Presentamos el caso de un paciente que desarrolló un absceso subescapular espontáneo que se drenó mediante un abordaje delto-pectoral, accediendo al espacio subescapular por vía medial a la coracoides. La relevancia del caso presentado radica en su singularidad y en la descripción de una vía de abordaje que solo ha sido empleada en dos casos previos en la literatura.

Palabras clave. Absceso subescapular. Espontáneo. Abordaje delto-pectoral. Artritis séptica. Infección.
Orthopedic Surgery and Traumatology. Complejo Hospitalario de Navarra. Pamplona.Spain.

Received: November 26, 2019

Revised: December 30, 2019

Accepted: March 3, 2020

\section{Corresponding author:}

Maitane Fernández Pérez

Servicio de Cirugía Ortopédica y Traumatología

Complejo Hospitalario de Navarra

C/ Irunlarrea, 3

31008 Pamplona

Spain

E-mail: fernandezmaitane91@gmail.com 


\section{INTRODUCTION}

The infections of the subscapular space are infrequent findings; in the bibliographic review performed, only eleven cases were identified until $2018^{1-10}$, six of them in children $^{1-5}$ and five in adults ${ }^{6-10}$. Most of the cases where caused by Staphylococcus aureus, and only two by Haemophilus Influen$z a e^{1,6}$. The approach used for the drainage of the abscess is described in only seven cases: medial approach to the scapula in four $^{4-7}$, lateral approach to the scapula in one $^{9}$ and delto-pectoral approach in two of them ${ }^{3,8}$.

We report the case of a 44-year-old patient with a spontaneous subscapular abscess that was treated surgically. The drainage was performed through a deltopectoral approach, and the subscapular space was reached by medial access to the chorachoid.

\section{CASE PRESENTATION}

A 44-year-old patient, without any recent history of prior trauma or infiltration, was referred to the Emergency unit with a 10-day history of left shoulder pain that was worsening in spite of anti-inflammatory treatment (dexketoprofen 25 $\mathrm{mg} / 8 \mathrm{~h}$ and metamizole $575 \mathrm{mg} / 8 \mathrm{~h}$ ). He had a fever of up to $39^{\circ} \mathrm{C}$ since six days before, without any other focal point suspected.

During the initial evaluation, the shoulder was moderately warm, without erythema, swelling or fluctuating bulges. The pain increased with palpation of the shoulder, the infra and supraclavicular region, the intertubercular sulcus and the subscapular point. Active movement of the shoulder was limited.

The serum levels of inflammatory markers were high (C-reactive protein, CRP: $170 \mathrm{mg} / \mathrm{L}$, normal range: 0-3; erythrocyte sedimentation rate, ESR: $60 \mathrm{~mm} / \mathrm{h}$, normal range: $0-15$ ), so the patient was hospitalized for study. During the hospitalization, a shoulder ultrasonography was done, in which no effusion or collection were observed. In spite of that, as the CRP increased up to $236 \mathrm{mg} / \mathrm{L}$, he was treated with empirical antibiotic therapy (amoxicillin clavulanic $1 \mathrm{~g} / 8 \mathrm{~h}$ ).

Magnetic resonance imaging (MRI) was requested, which could not be performed due to the weight of the patient; so a computed tomography (CT) scan was performed with intrave- nous contrast. The CT scan revealed a multiloculated lesion with heterogeneous captation (11x5x12cm), which took up almost all the subscapular region. (Fig. 1).

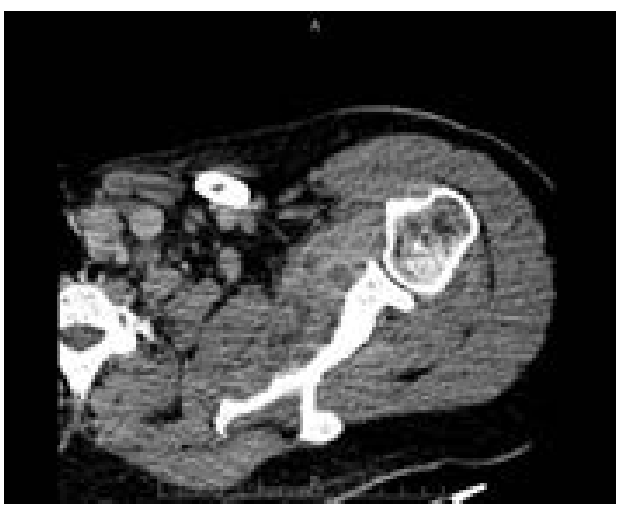

Figure 1. Computed tomography scan with intravenous contrast. Multiloculated lesion with heterogeneous contrast enhancement occupying practically the entire space of the subscapular region.

The patient underwent surgery under general anaesthesia and a delto-pectoral approach was performed (Fig. 2A). The clavi-pectoral fascia was exposed (increased and tense) and, after it was opened, not much purulent fluid drained out. Slough tissue was observed close to the long head tendon of the biceps. A tenotomy was performed parallel to the subscapular muscle and the capsule was opened. The slough tissue in the gleno-humeral joint, the rotator recess and the subscapular region was removed.

The medial of the conjoined tendon was exposed and the pectoralis minor was sectioned. We identified the musculocutaneous nerve and it was separated medially next to the plexus. The subscapular muscle layer was reached and we continued to open it longitudinally from lateral to medial. We exposed the layer between the subscapular muscle and the anterior wall of the scapula, as well as the intramuscular layers of the subscapular, extracting a large amount of purulent fluid (Fig. 2B). Exhaustive surgical cleaning was performed from the medial and anterior region of the subscapular fossa to the gleno-humeral joint. The tissues were closed leaving a surgical drain and prophylactic antibiotic treatment was started: $1 \mathrm{~g}$ of cefazoline every 8 hours and $240 \mathrm{mg}$ of gentamicine every 24 hours. 

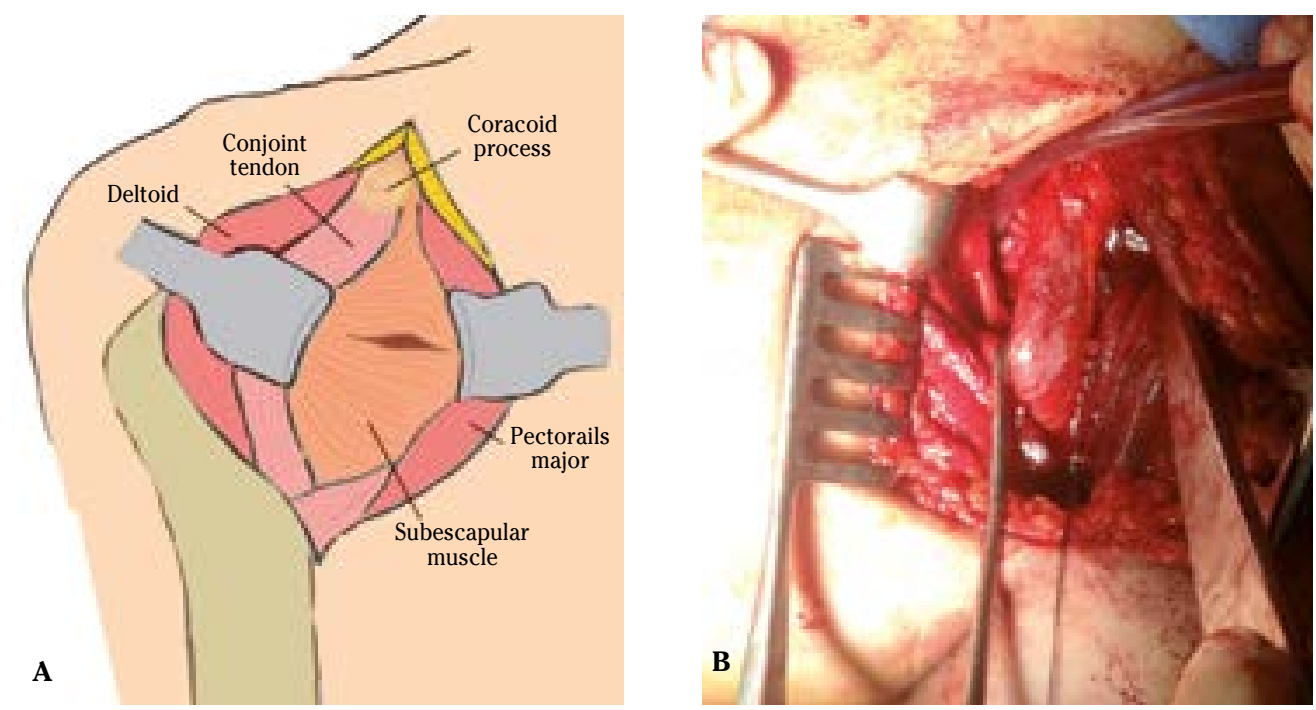

Figure 2. A. Diagram of the delto-pectoral approach performed. B. Exposure of the subscapular cavity through the deltopectoral approach; referencing the joint tendon.

Penicillin-resistant $S$. aureus grew in the cultures of the drained material, so treatment was begun with intravenous cloxacilin $6000 \mathrm{mg}$ every 12 hours and continued for three weeks, when it was changed to levofloxacin $750 \mathrm{mg}$ every 24 hours for another fifteen days.

The recovery of the patient was good, with a progressive decrease in inflammatory parameters (CRP $10 \mathrm{mg} / \mathrm{L}$ and ESR $5 \mathrm{~mm} / \mathrm{h}$ one month after surgery). During the late postoperative period, three months after surgery, he needed physical rehabilitation therapy because of joint stiffness. He did active-assisted kinesitherapy, glenohumeral capsule flexing exercises and Codman's pendular exercises. Finally, seven months after surgery, he achieved complete joint balance except for the final degrees of internal rotation, reaching as far as the dorsal region.

\section{DISCUSSION}

Subscapular abscess is an unusual surgical condition. The aetiology in previously described cases is not clear, although some authors suggest the presence of risk factors like immunosuppression, diabetes, previous infections in other localizations or the presence of a previous trauma. In this case, the patient lacks any of the named risk factors.
The exceptional nature of this pathology can delay diagnosis. Furthermore, in most cases, the patients have shoulder pain and diminished gleno-humeral mobility, in addition to infectious systemic symptoms, so it can be easily mistaken for septic gleno-humeral arthritis.

Subscapular abscesses can be a diagnostic challenge and, if this is delayed, can lead to a progressive and rapid worsening of the state of the patient ${ }^{10}$.

MRI is an essential tool for diagnosis, preoperative planning (after assessment of the area affected by the lesion) and treatment. However, in cases like this in which a MRI cannot be performed, a CT scan can resolve the diagnosis although preoperative planning is impaired by the difficulty in assessing the extent of injury with this test.

After diagnosis, treatment should be immediately applied to achieve favorable results. Due to the scarcity of published cases, there is no clearly defined treatment for this pathology; nevertheless, as in all abscesses, the treatment must include drainage, associated with antibiotherapy or not. Routine use of post-drainage antibiotic therapy is controversial; although 
some studies in adults and children do not recommend this ${ }^{11,12}$, most of these studies refer to superficial abscesses and the subscapular abscess cannot be considered superficial.

The delto-pectoral approach for the drainage of the abscess was only used in two of the previously described cases, although the procedure is not clearly explained. Considering the scarcity of published similar cases, we chose the approach that we use most commonly, since it allows correct drainage of the subscapular space between intermuscular layers without damaging noble structures. This, in conjunction with early rehabilitation, could be helpful in obtaining good functional results. More cases are needed to establish the best approach for surgical treatment.

In conclusion, the relevance of this case lies in its rarity, which can cause delays in diagnosis with negative consequences for the functionality of the scapulo-humeral joint. In addition, the delto-pectoral approach used for surgery, only used twice for this pathology, is described in detail so that it can be reproduced.

\section{REFERENCES}

1. SAn Joaquin VH, Kimball JB. Subscapular abscess due to Haemophilus influenza type B. Pediatrics 1980; 65: 331-332. https://doi. org/10.1542/peds.65.2.331

2. Babayığit $\mathrm{A}$, MaKay $\mathrm{B}$, Demircioğlu $\mathrm{F}, \mathrm{CAK}-$ MAKÇI $H$, Unsal E. Subscapular abscess after blunt trauma. Pediatr Emerg Care 2009; 25: 399-400. https://doi.org/10.1097/ PEC.0b013e3181a7927d

3. Yllmaz G, Standard SC. Periscapular abscess: unusual cause of shoulder pain in children.
J Pediatr Orthop B 2012; 21: 310-312. https:// doi.org/10.1097/bpb.0b013e328349139a

4. Giugale JM, Bosch PP, GrudziaK JS. Subscapular abscess in a nine-year-old female patient. JBJS Case Connect 2015; 5: e13. https://doi. org/10.2106/jbjs.cc.n.00102

5. Hany Mourkus, Ramanan Vadivelu, James Phillips. Literature review and a case report of spontaneous subscapular abscess in a child. Eur J Orthop Surg Traumatol 2018; 28: 1235-1240. http://dx.doi.org/10.1007/s00590-018-2156-4

6. Nowinski RJ, Duchene C. Spontaneous septic subscapular abscess. A case report. J Bone Joint Surg 2004; 86: 1302-1304. https://doi. org/10.2106/00004623-200406000-00028

7. Saxena P., Konstantinov I., Zelei D., Newman MA. Spontaneous subscapular abscess: a rare surgical condition. Heart Lung Circ 2008; 17: $517-$ 518. https://doi.org/10.1016/j.hlc.2007.02.095

8. Patel K, Spowart E, Sochorova E, Diego N, MamaRELIS G, SoHall MZ. Subscapular abscess caused by Panton-Valentine leukocidin-Positive Staphylococcus aureus: an atypical presentation. Case Rep Orthop 2018; 2018: 8256428. http://dx.doi.org/10.1155/2018/8256428

9. Christman-Skieller C, McIntyre LK, Plevin R, FrieDRICH JB, SMITH DG. A Posterolateral Approach to the Scapula for Evacuation of a Subscapular Abscess. JBJS Case Connect 2017; 7: e57d. http://dx.doi.org/10.2106/JBJS.CC.16.00241

10. HANDORF CR. Fatal subscapular abscess. SouthMed J 1983; 76: 271. http://dx.doi. org/10.1097/00007611-198302000-00039

11. Schmitz GR. How do you treat an abscess in the era of increased community associated methicillin-resistant Staphylococcus aureus (MRSA)? J Emerg Med 2011; 41: 276-281. https://doi.org/10.1016/j.jemermed.2011.01.027

12. Duong M, Markwell S, Peter J, Barenkamp S. Randomized, controlled trial of antibiotics in the management of community-acquired skin abscesses in the pediatric patient. Ann Emerg Med 2010; 55: 401-407. https://doi. org/10.1016/j.annemergmed.2009.03.014 